\title{
Aikuiskasvatustutkimus pitkällä marssillaan
}

\author{
"Kun katselee aikuiskasvatustutkimusta, vaikkapa opinnäytetöitä, \\ havaitsee helposti paradigmaattisen kirjavuuden, monenlaista yrittämistä. \\ Ehkäpä kysymys on makuasioista, mutta minusta alalla on paljon positiivista \\ keskinkertaisuutta, sen sijaan todella hyvää, omaperäistä, ajatuksia \\ herättävää tutkimusta ei niinkään; sellaista kohtaa lähinnä yhteiskunta \\ tieteissä."
}

Eri tieteiden ja toimintojen aloilla kysymys tutkimuksen ja toiminnan suhteista näyttäisi olevan aito ongelma, joka on ratkennut eri tavoin. Aikuiskasvatuksen alueella suhde on varsin hankala.

Esimerkiksi lääketieteessä tutkimuksen ja lääkärintoiminnan suhde on varsin läheinen ja sillä on selkeät institutionalisoituneet muodot. Käsittääkseni myös esimerkiksi teknisten tieteiden, oikeustieteiden ja taloustieteiden alueilla suhteet tutkimuksen ja toiminnan välillä ovat pääosin vakiintuneet; profession käsitteeseenhän kuuluu ns. tiedeperusta.

Omat kokemukseni tieteen, tutkimuksen ja käytännön toiminnan suhteista ovat huomattavan ristiriitaiset. Olen väitellyt tohtoriksi psykologian alalla ja työskennellyt monta vuotta psykologina, ammatinvalintapsykologina. Nämä kaksi psykologian maailmaa eivät kokemukseni mukaan sisällöiltään juurikaan edes kosketa toisiaan. Toki on hallinnollinen yhteys: ei saa toimia psykologina, jos ei ole suorittanut psykologian laudaturia.

Olen myös opiskellut yhteiskuntatieteitä ja työskennellyt lukuisissa yhteiskunnallisissa suunnittelu- ja luottamustehtävissä. Yhteys tutkimuksen ja käytännön toiminnan välillä on minusta parempi kuin psykologiassa; ei vain niinkään ole kysymys tutkimuksen soveltamisesta kuin siitä, että tutkimus ja tieteellinen keskustelu tarjoavat resursseja, joista voi kehittää kulloinkin tarvitsemaansa käsitteellistä ja sisällöllistä välineistöä. Hallinnollinen yhteys sen sijaan on löysä.

Olen myös opiskellut ja opettanut aikuiskasvatusta yliopistossa sekä toiminut monenlaisissa aikuiskouluttajan ja koulutussuunnittelijan tehtävissä. Suhde toiminnan ja tutkimuksen välillä muistuttaa minusta tilannetta yhteiskunnallisen toiminnan ja yhteiskuntatieteiden välillä: on paljon mahdollisesti käyttökelpoista tutkimusta ja ajattelua, jonka kehittäminen toiminnan resursseiksi on oma tehtävänsä.

Aikuiskasvatuksellisesti adekvaatti tutkimus on suunnattomasti laajempi asia kuin aikuiskasvatustutkimus. jos aikuiskasvatusta ei rajoiteta organisatoris-hallinnollisiin määrittelyihin, vaan ymmärretään sen olevan aspektina hyvin monissa elämänilmiöissä, siinä hyväksi käytettävän tutkimuksen ja ajattelun ala on hyvinkin laaja ja vaikeasti määriteltävissä.

Toisaalta on sellainen tosiasia kuin institutionalisoitunut aikuiskasvatustutkimus: aikuiskasvatus yliopistollisena oppiaineena ja tieteenalana. Voidaan ajatella aikuiskasvatustutkimus omaksi kollektiivitoimijakseen tai "yrittäjäkseen", joka muodostaa omaa ekologista lokeroansa sosiaalisessa ympäristössään.

Suomalaisen akateemisen aikuiskasvatustutkimuksen vuorovaikutusympäristössä hahmottuu helposti muutama lohko. Ensinnäkin on akateeminen lähiympäristö: yhteistyö- ja kilpailutieteet kuten kasvatustiede, psykologia, sosiologia. Näiltä lainataan, näihin verrataan. Toiseksi on kenttä. Ehkä tärkein side on opetus ja 
pätevöittäminen. Tässä suhteessa, aikuiskasvatusprofession kehittymisessä, ollaan aika epämääräisessä tilanteessa. Kolmas lohko on aikuiskasvatustutkimus ja keskustelu kansainvälisellä tasolla; tämä ymmärtääkseni nykyään "vetää" aikuiskasvatustutkimuksen asemaa entistä vahvemmaksi.

Kun katselee aikuiskasvatustutkimusta, vaikkapa opinnäytetöitä, havaitsee helposti paradigmaattisen kirjavuuden, monenlaista yrittämistä. Ehkäpä kysymys on makuasioista, mutta minusta alalla on paljon positiivista keskinkertaisuutta, sen sijaan todella hyvää, omaperäistä, ajatuksia herättävää tutkimusta ei niinkään; sellaista kohtaa lähinnä yhteiskuntatieteissä.

Havaitsee myös tutkimusten olevan johonkin vuorovaikutusympäristön lohkoon kallellaan. Useat, ehkä useimmat tutkimukset ovat otteeltaan psykologisia tai sosiologisia mieluummin kuin kasvatuksellisia; ne eivät kuitenkaan edusta psykologian tai sosiologian "terävintä" kärkeä, niillä ei ole noiden alojen ambitioita, vaan ne ovat mieluummin laimennettua psykologiaa tai sosiologiaa. On myös tutkimuksia, jotka ovat "käytännöllisiä" siinä mielessä, että ne ovat sidoksissa johonkin konkreettiin kenttään, mutta niillä taas on laajempien keskusteluyhteyksien ja yleistysten muodostamisen vaikeuksia. On myös kansainvälisen tason aikuiskasvatuskeskustelun hyväksikäyttöä; ikävä kyllä usein vain ulkokohtaisesti esittelevää, käsitteitä ikään kuin resepteinä ottavaa mieluummin kuin reproduktiivista, uudelleentuottavaa.

Aikuiskasvatustutkimus on vahvistumisen ja identiteettinsä muodostumisen pitkällä marssilla. En ole varma asiasta, mutta tuntuisi, että suhteessa ns. lähitieteiden, vaikkapa psykologian ja sosiologian paradignioihin ja kriteereihin kannattaisi etsiä itsenäistymisen mahdollisuuksia. Ideana mainitsen Tampereen yliopiston tiedotusopin vaihtoehtogradun. Siinä on journalistinen tuote - radio- tai tv-ohjelma; artikkeli, mainos tai esite taikka sellaisen graafinen ratkaisu, jne. - sekä tuotetta ja sen kehittelyä koskeva problematisointi - ja keskustelupaperi lähdekirjallisuuksineen. Olisiko jokin tämäntapainen tutkimusote aikuiskasvatuksessa kehittelyn arvoinen? Ehkäpä se avartaisi käytäntöön suuntautunutta tutkimustoimintaa, ja vahvistaisi itsenäistymistä psykologien ja sosiologian paradigmoista. 